\title{
A feasibility study of application of solution prepared by mixing castor oil and turmeric powder to prevent infection with leptospirosis in Ambach village, Surat, Gujarat, India
}

\author{
Abhay Kavishvar, Mamtarani Verma* \\ Department of Community Medicine, Government Medical College, Surat, Gujarat, India \\ Received: 13 December 2015 \\ Revised: 21 January 2016 \\ Accepted: 23 January 2016 \\ *Correspondence: \\ Dr. Mamtarani Verma, \\ E-mail: psmmamta@yahoo.co.in \\ Copyright: (c) the author(s), publisher and licensee Medip Academy. This is an open-access article distributed under \\ the terms of the Creative Commons Attribution Non-Commercial License, which permits unrestricted non-commercial \\ use, distribution, and reproduction in any medium, provided the original work is properly cited.
}

\begin{abstract}
Background: Leptospirosis is an acute infection caused by spirochetes belonging to the genus leptospira that can lead to multiple organ involvement and fatal complications. Objectives were to study the acceptance solution prepared by mixing turmeric powder with castor oil, a protective measure against leptospirosis and the feasibility of use of that measure at mass level.

Methods: Study was conducted in Ambach village. Group discussion in the meeting at Community Center as well as in the farm when at risk people were actually at work was conducted in the month of June-July 2008. Application of Castor oil and turmeric solution (CT solution) was demonstrated. Solution or a paste prepared by mixing turmeric and castor oil should be applied on the whole surface of both the legs which comes in contact with water in the field. All those who go to field should apply it and provide the feedback in the next group meeting. No statistical tests were applied and results were obtained simply as their feedback.

Results: In the form of feedback were from farm workers on inquiring about the trial.1. Families tried it but did not ask for more amount of such solution. 2. It disappeared quickly hence of no use.

Conclusions: It can be concluded that farmers, agricultural labourers and other people are not yet prepared to adopt personal protective measures which they feel is not effective, requires daily and regular application and is not affordable. Other known options like early detection and prompt treatment and chemoprophylaxis can be better available as and when sought.
\end{abstract}

Keywords: Leptospirosis, Feasibility study, Turmeric powder, Castor oil

\section{INTRODUCTION}

Leptospirosis also known by various names like "Weil's disease", "Pretibial fever", "Fort Bragg fever", "Peapicker's fever" in different parts of the world is an acute bacterial infection caused by spirochetes belonging to the genus Leptospira that can lead to multiple organ involvement and fatal complications. ${ }^{1}$ It has been recognized as the most common zoonotic infection in the world. ${ }^{2}$ The incidence is higher in the tropics than in temperate regions. ${ }^{3}$ Most countries in the South East Asia region are endemic to leptospirosis. ${ }^{2}$ People can be considered at risk because of social, occupational and reasons. Its Incidence seems to be increasing in developing countries. On an average 10,000 severe cases requiring hospitalization occur annually all over the world.

A number of leptospirosis outbreaks have occurred during the past few years in various countries particularly in South America and India. ${ }^{4-8}$ Leptospirosis presents in a wide spectrum of clinical presentations. ${ }^{9}$ There is lack of 
awareness among medical professionals and availability of laboratory services lacks in most of affected countries. $^{10,11}$

Although the basic principles of transmission of leptospirosis infection i.e presence of carrier animal, suitability of the environment for the leptospira and unprotected exposure of the people to contaminated environment are applicable to all epidemiological situations, the exact transmission of dynamics differs from place to place. Without a clear understanding of these details it might not be possible to plan an intervention strategy targeting the carrier animals, environment and human behaviour modification to reduce the risk of exposure. Measures targeting human population are simple as these do not depend upon the complexities of transmission dynamics.

The possible measures are vaccination and chemoprophylaxis of people at risk. A major hurdle in development of effective vaccine is existence of a large number of serovas of leptospirae. Chemoprophylaxis had only $54 \%$ protective effect against symptomatic leptospirosis and does not prevent leptospiral infection.

Turmeric and castor oil are well accepted substances in this society. People all over the country use both these substances in their day to day life since centuries. Turmeric extract has been shown to have antiseptic and anti-oxidant properties. Curcumin has been used extensively in ayurvedic medicine for centuries, as it is nontoxic and has a variety of therapeutic properties including antioxidant, analgesic, anti-inflammatory, antiseptic activity, and anticarcinogenic activity. ${ }^{12}$

It mixes well with castor oil making a solution which is easy to apply. Castor oil acts as barrier to water and keeps the water away from the surface when applied in enough quantity.

It has been thought that if a solution prepared from dry turmeric powder and castor oil is applied to the body parts mainly limbs exposed to contaminated water of field protects from; leptospiral infection, can be an effective way to reduce the exposure of people to the leptospirosis.

\section{Aim and objectives}

Aim and objectives of the study are,

1. To study the acceptance solution prepared by mixing turmeric powder with castor oil, a protective measure against leptospirosis.

2. To study the feasibility of use of that measure at mass level.

\section{METHODS}

1. Study was conducted in Ambach village of Valod taluka of Surat district of Gujarat state. The village is about $50 \mathrm{~km}$ away from Surat city and has previously reported the cases and deaths due to leptospirosis.

2. Group discussion in the meeting at Community Center as well as in the farm when at risk people are actually at work was conducted in the month of June-July 2008.

3. Opinion from the successful farmer, local health functionaries and representatives from NonGovernmental agency was taken.

4. Demonstration of the application of Castor oil and turmeric solution (CT solution) and reassurance of providing it as per the need free of cost.

5. Providing trial packs to a few families and observing them for expression of interest. Each pack contains $200 \mathrm{ml}$ of castor oil and $100 \mathrm{gm}$ of turmeric powder. Solution or a paste prepared by mixing turmeric and castor oil should be applied on the whole surface of both the legs which comes in contact with water in the field. All those who go to field should apply it and provide the feedback in the next group meeting. Feedback should also be provided to ASHA (Accredited Social Health Activist) worker.

6. Training and monitoring of three ASHA (Accredited Social Health Activist) workers for this trial.

7. A local voluntary health agency (Vedchhi Pradesh Sewa Samiti) was also involved to contact people and to mobilize them in this respect.

\section{RESULTS}

In a meeting with health workers, it was decided to organize a meeting of people who actually go to the field for variety of activities related to farming. It was clear that these health workers will motivate and call people to attend this meeting. A time which was convenient to these agricultural labourers was fixed. Unfortunately on that day initially only 4-5 people came to the venue of meeting place. Efforts were made to bring people in vehicles and finally around 50 people gathered at community hall in Ambach village. Surprisingly eighty percent of this group consisted of women. During discussion following information could be collected.

Most of the adult population of the village work in the farm and mainly rice fields during these days. Another important crop is cane sugar. Men and women go to field regularly and daily. They work for their farm as well as for neighbours/relatives farm.

Discussions were generated about whether they have heard about leptospirosis and know anything about leptospirosis. They were told about the common mode of 
transmission of this disease to farm workers and agricultural labourers.

It was said that they do not use any type of footwear during any activity in their farm. They were clear that is not possible to work with any type of footwear in rice field especially when the field is filled with water and mud.

As per their perception some of them will have cracks on their feet earlier whereas others will develop later. Majority of workers will develop such cracks as they start working in the rice fields. These cracks when become painful, people apply edible oil or mehndi to it at night. People were told that a mixture of castor oil and turmeric powder if applied to the body parts coming in contact with field water may protect them from infection of leptospirosis. All of the people attending meeting were motivated to try out it and give the feedback in meeting next week.

Unfortunately nobody came to attend the meeting next time. A few feedbacks were available to health workers are summarized below.

1. People do not have oil even to use as edible thing and applying turmeric and oil daily to the feet was not affordable.

2. People who tried at least once replied that such solution did not stay on feet and goes away within no time.

3. According to some people, it is not practical as going to farm is a daily activity.

It is easier to get people in the farm/field which we did today. It is advisable to reach to the spots where they work and motivate them to adopt various preventive measures against leptospirosis as they may not have time to attend our meeting at health center or any other constructed site in the village. Many labourers walk a sizable distance to reach to their place of work (farm) away from their dwellings. It is difficult to call these agriculture workers to the meeting place for even two hours in this busy season. There remains a shortage of workforce for farming. These daily wagers earn around 30-40 rupees a day and many of them spend daily ten rupees for alcohol. In such circumstances they do not spare time for any other activity in this season. In short, they need to be addressed in the farms when they work or rest for a while for sensitization or reinforcement.

All the agricultural labourers to whom we met told that it is impossible to work with any type of footwear for them in the field. It is difficult for them to walk on sides of farm with conventional footwear.

Mrs. Harshida Gamit, an ASHA worker who was present in previous meeting did not use castor oil and turmeric powder solution. She did not tell her husband about its use although both of them regularly go to their farm.
When we asked why they did not adopt application of CT solution? She replied: "going to farm and work is a daily affair and hence..." When asked about other people she told that it is costly for people.

Two farmers were interviewed about the retention of this CT solution while working here in the rice field filled with water. He told that currently I am creating mud before putting rice dharu/taru in this area. I don't think that any solution can stay with legs after working in this mud. Another person added that "I know that somebody who applies mehndi as a therapy for cracks of feet, its colour disappears after working in such a mud."

Tomorrow we have planned to see whether CT solution stays on legs.

It has also been mentioned that the duration of work in such a field is quite longer, up to six hours which makes it difficult to persist.

Three ASHA workers of Ambach village were sensitized regarding the use of CT solution as part of preventive measures against leptospirosis. They were also asked to select 3 families to whom they can visit and monitor about the application of CT solution.

They were given the necessary amount of turmeric powder and castor oil. All the three ladies having their own farm were also told to try it out for the self. Following are the feedback from them on inquiring about the trial.

1. Families tried it but did not ask for more amount of such solution.

2. It disappears quickly hence of no use.

3. Going field is twice a day activity so it becomes tiresome.

After entering in to rice field filled with water and mud, if one comes out, most of the solution goes away. She clearly mentioned showing the mud and water around that it cannot work in such situation.

Mr. Lalsingh a volunteer from the group was given a CT solution, prepared from castor oil and turmeric in front of them and they entered inside the rice field. They walk a few steps in that area filled with mud and water; the solution disappeared in no time. It is the friction of legs and feet inside the field ready for seeding with mud and water which removes the paste of turmeric and castor oil applied to it.

Saiyedbhai raised the point that because the paste/CT solution was applied on wet/soiled legs, it did not remain sticked to the legs or feet.

As an effort when the same solution was applied to dry hands and the hands were moved in the mud water, it again disappeared. 


\section{DISCUSSION}

Leptospirosis affects human beings and many other species of vertebrates. ${ }^{2}$ Most commonly, the infection is acquired by direct or indirect exposure to urine of reservoir animals through contaminated soil, mud \& water entering via small abrasions or breaches in the skin $\&$ mucous membranes during occupational, recreational or vocational activities. ${ }^{13}$ Application of a solution prepared from dry turmeric powder and castor oil to the body parts mainly limbs was tried as an effective protective to reduce the exposure of people to the leptospirosis.

Unfortunately, the persistence of the solution remains doubtful for even minutes once the worker starts working in the rice field. A slightest stickiness can be felt on touch but on turmeric powder can be seen.

The whole group of working farm labourers mainly women did not show faith or confidence about this measure and when asked about the alternative they could not suggest anything.

It can be concluded that Farmers, agricultural labourers and other people are not yet prepared to adopt personal protective measures which they feel is not effective, requires daily and regular application and is not affordable. Other known options like early detection and prompt treatment and chemoprophylaxis can be better available as and when sought.

Transmission dynamics is not well known to people and not even fully understood for the region. General guidelines do not appeal to modify their earlier behaviour and years old techniques.

Shortage of agricultural labourers and unorganized sector of farm workers makes the use of legislative measures compelling them to use improbable.

Lack of any live example of similar kind of measure makes the arguments inconvincible.

Community does not have people who can mobilize the vulnerable group to try out this measure for prevention. Grass root workers and even middle level workers or volunteers cannot influence the masses to use the CT solution.

Epidemiology of leptospirosis is not much known to people and health is not a first priority for these daily wagers. There are no pathogonomic signs or symptoms which can frighten the people to go for adopting a new preventive measure. Symptoms and signs mimic a few common ailments in the area which are self limiting or can be cured easily. The disease does not have local name although there are many names mentioned in the medical literature. Disease detection in this area is comparatively a recent phenomenon in this context (around a decade) and hence people have not heard from their parents about leptospirosis.

What we can recommend from such a study is enough epidemiological information especially transmission dynamics must be known before undertaking such interventions. Compliance of people and cost of such preventive measures when thought for mass level intervention should also be considered equally important. Suitability of such intervention is always questionable and provision should be made for it.

Leptospirosis, being a zoonotic disease with a large variety of animal species acting as carriers, is difficult to eliminate and perhaps even control in tropical developing countries. The bacteria are adapted to the environment of the tropical region with plenty of rainfall and it is often difficult to avoid exposure of the people to animals or contaminated environment. Early detection and prompt treatment and creating awareness about the disease among the people and the public health professionals are the steps that could be taken to reduce the magnitude of the problem. ${ }^{14}$

\section{CONCLUSION}

It can be concluded that farmers, agricultural labourers and other people are not yet prepared to adopt personal protective measures which they feel is not effective, requires daily and regular application and is not affordable. Other known options like early detection and prompt treatment and chemoprophylaxis can be better available as and when sought.

\section{ACKNOWLEDGEMENTS}

Authors are thankful to the ex-Professor and Head of the Department Dr. Vikas K. Desai for providing all the technical support. Authors are also thankful to all the participants who had co-operated very well in this study.

Funding: No funding sources

Conflict of interest: None declared

Ethical approval: The study was approved by the Institutional Ethics Committee

\section{REFERENCES}

1. Stuart WT. Spirochetes. In: Saunder's Text and Review Series, Philadelphia, Pennsylvania, W.B, Saunders company. 1998:236-51.

2. Vijayachari P. Introduction. In: Leptospirosis Laboratory Manual, Regional Medical Research centre, Port Blair, WHO Country office for India, WHO. 2007:1-3.

3. Narita M, Fujitani S, Haake DA, Paterson DL. Leptospirosis after recreational exposure to water in the Yaeyama islands, Japan. Am J Trop Med Hyg. 2005;73(4):652-56. 
4. Zaki SR, Sheih WJ. Leptospirosis associated with outbreak of acute febrile illness with pulmonary haemorrhage, Nicaragua. The epidemic working group at Ministry of health in Nicaragua. Lancet. 1996;347(9000):535-6.

5. Ko AL, Reis MG, Dourado CMR, Johnson WD, Riley LW. Salvador Leptospirosis Study group. Urban epidemic of severe leptospirosis in Brazil. The Lancet. 1999;354:820-5.

6. Sehgal SC, Sugunan AP, Vijayachari P. Outbreak of leptospirosis after cyclone in Orissa. National Med J India. 2001;15(1):22-3.

7. Sehgal SC, Murhekar MV, Sugunan AP. Outbreak of leptospirosis with pulmonary involvement in North Andman. Indian J Med Res. 1995;102:9-12.

8. Singh SS, Vijayachari P, Sinha A, Sugunan AP, Rashid MA, Sehgal SC. Clinico- epidemiological study of hospitalized cases severe leptospirosis. Indian J Med Res. 1999;109:94-9.

9. Ramachandran S, Perera MVF. Cardiac and pulmonary involvement in leptospirosis. Trans Royal Soc Trop Med Hyg. 1977;71(1):56-9.
10. Silvia RRV, Brauner JS. Leptospirosis as a cause of acute respiratory failure: clinical features and outcome in 35 critical care patients. Brazilian $\mathbf{J}$ Infect Dis. 2002;6(3):135-9.

11. Muthusethupathy MA, Sivakumar S, Vijayakumar $\mathrm{R}$, Jayakumar M. Renal involvement in leptospirosis - our experience in Madras city. J Post Graduate Med (India). 1994;40(3):127-31.

12. Çýkrýkçý S, Mozioglu E, Yýlmaz H. Biological activity of curcuminoids isolated from Curcumalonga. Rec Nat Prod. 2008;2:19-24.

13. The Spirochetes. In: Betty AF, Daniel FS, Alice SW, (eds.), Bailey \& Scott's.Diagnostic Microbiology, 12th ed, St. Louis, Missouri, Mosby Elsevier. 2007:539-40.

14. P. Vijayachari. Leptospirosis Laboratory manual, World health organization. 2007.

Cite this article as: Kavishvar A, Verma M. A feasibility study of application of solution prepared by mixing castor oil and turmeric powder to prevent infection with leptospirosis in Ambach village, Surat, Gujarat, India. Int J Community Med Public Health 2016;3:625-9. 